UDC 616.31:616.33/.34-002]-053.3/.5

Maksymenko A.I.

\title{
SIGNS OF DISEASES OF THE GASTROINTESTINAL TRACT IN THE ORAL CAVITY OF CHILDREN
}

Poltava State Medical University, Poltava, Ukraine

\section{Introduction}

One of the main places in the structure of diseases of the child population belongs to chronic diseases of the digestive system. Their prevalence among children ranges from $58.1 \%$ to $100 \%[1,2$, $3]$. Thus, the number of children with chronic gastroduodenitis has increased by 10.1 times, the number of adolescents with peptic ulcer disease has increased by 1.7 times, and the proportion among children with diseases of the digestive system has gone from $14.5 \%$ to 55 . $3 \%$ over the past 10 years $[4,5]$.

The question of combined lesions of the oral cavity and internal organs occupy a prominent place among the problems of dentistry nowadays. They allow to reflect the genesis of many diseases that manifest themselves in the oral cavity $[6,7]$.

Aim of the study was to analyze information on the relationship of diseases of oral cavity and various diseases of gastrointestinal tract (GIT). It was made to value the future prospects of development of therapeutic prophylaxis an treating some dental diseases, such as lessions of hard dental tissues, gingivitis and periodontitis.

\section{Research results and discussion}

It can be difficult to single out the specific importance of each link in this system. The involvement of some organs (wich are connected with the gastrointestinal tract) in the pathological process is accompanied by disruption of their activity, and possible development of severe changes in all the digestive system. It is important to identify the relationship between the oral cavity and diseases of the digestive organs along with the study of clinical manifestations developing as a result of intestinal damage. It makes possible to clarify not only the pathogenesis of number of pathological processes, but also to improve diagnostics, the choice of treatment and prevention methods $[8,9]$.

The oral cavity is functionally closely connected with the entire human body and directly with the gastrointestinal tract. The mucous membrane of the oral cavity is a site of reflex action of various parts of the gastrointestinal tract, and at the same time, its receptors affect the secretory and motor activity of the gastrointestinal tract $[10,11]$.

Anatomical and physiological proximity, common innervation and humoral regulation leads to the involvement of organs of oral cavity in the pathological process [12]. Inflammatory processes in periodontium $[2,13,14]$ and in the mucose membrane of the mouth $[3,6]$, changes in salivary glands [11, 15], caries [16, 17] and non-carious [18] lesions of dental hard tissues often occur in patients with gastrointestinal diseases.

On the other hand, pathological processes in the oral cavity become reasons of chronic infection. They violate on the act of chewing, lead to a deterioration in the functioning of the gastrointestinal tract and exacerbation of its chronic diseases [19]. It is known, that the combination of diseases of the oral cavity and internal organs is accompanied by the development of endogenous intoxication. The development of major dental diseases, accompanied by a gradual disruption of occlusion and chewing efficiency, also leads to an increase of chronic forms of gastrointestinal tract pathology. For example, the most common diseases of the gastrointestinal tract are chronic gastritis and bacterial overgrowth syndrome in patients with secondary reduced occlusion [20].

Catarrhal gingivitis, stomatitis are often caused by deficiency of vitamins of group B. Abovementioned deficiency is caused, according to many scientists, by the diseases of gastrointestinal tract. And such diseases of the oral cavity as chronic recurrent stomatitis, lichen planus, chronic recurrent herpetic stomatitis, chronic periodontitis depends on the pathology of the digestive tract $[19,21]$.

Changes in the oral mucosa in chronic diseases of the gastrointestinal tract are usually nonspecific. They are manifested by color changes, swelling during periods of exacerbation of the underlying disease, specific plaque on the tongue, diffuse desquamation of the epithelium on the dorsal surface of the tongue, thinning of certain areas of the oral mucosa, by gum inflammation of various severity $[3,8]$.

We should note the importance of Helicobacter pylori colonization in the occurrence of such diseases of gastrointestinal tract, as gastric ulcer, duodenal ulcer. In children, Helicobacter pylori is found in the oral cavity in $83 \%$ of examined children [22].

A lot of research works show that Helicobacter pylori can manifest itself in the stomach of a child from the first months of life. Gastroenterologists found Helicobacter pylori in 2-6-9 month old children [23].

There are numerous factors of Helicobacter pylori transmission, such as contact of some items with saliva, for example, oral hygiene items, cutlery. Lickin of infants' pacifiers by parents is also a source of infection. 
Research works indicate that Helicobacter pylori is determined in the biofilm of periodontal pockets and dental plaque in patients with generalized periodontitis and gastric ulcer or duodenal ulcer [24, 25].

It has been proven that gastroesophageal and duodeno-gastroesophageal refluxes in preschool children leads to lesions of the oral mucosa and of hard dental tissues [26]. The presence of bile acids in the oral cavity is a diagnostic sign of duodenogastroesophageal reflux in preschool children. The composition of the oral fluid is determined by the form of the reflex in children with reflux disease [27].

It is known that the concentration of histamine in the blood serum increases and at the same time the activity of histaminase decreases, as well as the activity of hyaluronidase increases in case of gastric ulcer. Peptic ulcer of the stomach and duodenum leads to an increase in protein-bound hydroxyproline, elastase and glycosaminoglycans of saliva, a decrease in ascorbic and dinur ascorbic acids, as well as to a decrease of local immunity of the oral cavity [3].

The decrease of the oral mucosa reactivity is observed in general acute peptic ulcer disease. The reaction of the salivary glands to mechanical and chemical contamination of gastric receptors is altered. Children with this pathology suffer from gum bleeding (gingivitis), hypertrophy of the tongue papillae, the aphthae and ulcers on the oral mucosa [28].

The degree of chewing dysfunction and the formation of occlusion pathology correlates with the level of oligopeptides and substances of low and medium molecular weight in the blood, erythrocytes, urine, saliva [29].

The calcium-regulatory system changes (these changes affect the state of the periodontal tissues) in people with gastrointestinal diseases (T.I. Vlasova, 1988). System processes play an essential role in pathogenesis of generalized periodontitis. They lead to profound changes in whole organism in general, and as a consequence to local distruction in periodontium [14].

It was found that chronic recurrent stomatitis occurs together with intestinal dysbiosis [30]. The electrophoretic activity of buccal epithelial cells in children with intestinal dysbiosis differs from those in healthy children. The percentage of mobile cell nuclei and plasmolemas in children with dysbiosis is lower than in practically healthy children. There is a decrease in the ratio of the plasmolemas' amplitude and the nucleus' amplitude of the buccal epithelium cells. It indicates a decrease in protective reactions in the oral cavity [31].

Changes in metabolic processes are observed in children with intestinal dysbiosis (a decrease in the amount of ionized calcium and inorganic phosphorus in the oral fluid). It affects the mineralization of dental hard tissues and their acid resistance [32]. It has been proven that the acid resistance of the enamel is less in children with intestinal dysbiosis, than in healthy children [16].

A high level of mycoplasma, herpes virus, cytomegaly, Epstein-Bar, Coxsackie A and B was found in buccal scraping in children with irritable bowel syndrome and ulcerative colitis (Karabushina Ya., 2004).

Lebedenko V., I. Maev, E. A. Kamenshik (2002) described the primary and secondary manifestations of ulcerative colitis and Crohn's disease in the mouth.

The mucous membrane of the oral cavity is constantly exposed to external factors, and it is the boundary barrier between the upper digestive tract and the external environment. The high frequency of mixed infections has a modulating effect on the course of the processes of oral mucosa reparative regeneration. Long-term persistence of this infection leads to organic changes in cells, namely, the proliferative metabolic activity of epithelial cells increases. The functional state of the mechanisms of specific and nonspecific defense against infection plays a role in the development of dysbiosis of the oral cavity $[33,34]$. Molecular biological proof of the presence of this infection is important and informative. It is usually carried out using polymerase chain reaction and DNA hybridization in solution.

The relationship between the state of immunity and the processes of regeneration has been proven nowadays, while the oral cavity has an autonomous immune system. These are lymphoid structures and macrophages, as well as humoral factors of saliva: lysozyme, immunoglobulins of classes $A, M, G$ and slgA, wich is secreted locally in the oral cavity. They can also get into the oral cavity through the vascular wall from the blood. Dissemination of infection in the body occurs together with the changes in the immune system, namely, the deficiency of the T-system of immunity and deterioration of local immunity (slgA). The main changes are the decrease in the activity of NK-cells, the proliferative response of $\mathrm{T}$-lymphocytes to antigens, and inhibition of the ability of T-lymphocytes to differentiate Thl-cells [35].

Some authors indicate that there is a clear tendency to an increase of IgM level in the blood serum, both in diseases of the gastroduodenal and digestive systems in children [5,35]. Many authors explain the increased level of IgM in serum, as a compensatory response associated with a tendency to decrease the level of $\lg A$ in it. Reduction of $\lg A$ in serum was found in children with chronic gastritis, gastroduodenitis, chronic diseases of liver and biliary tract, duodenal ulcer [5].

Most researchers found an increase in the level of $\lg A$, including its secretory form slgA, in the mixed saliva of children with various forms of diseases of the gastrointestinal tract. It may be associated with both the above-mentioned disease and the presence of a chronic inflammatory process in gums [2]. At the same time, the concentration of slgA in the oral fluid of children with chronic diseases of the digestive system can exceed the same indicator in healthy children by 1.5-2.0 times [35].

The reduced resistance to colonization is expressed in a significant reduction of the level of Neisseria spp. The immunity of the oral mucosa in 
these children contributes to the intensive inflammatory reactions. It is evidenced by the increase of IL-10 in saliva [4].

\section{Conclusion}

Thus, anatomical and physiological characteristics of children, who suffers from chronic gastrointestinal diseases, make us study the clinical manifestations of dental diseases in these patients. The interest in the study of this problem can be explained by the accumulation of new facts, the emergence of new information about the interstitial, intercellular level of interaction in the system of the whole organism. The mechanisms of mutual influence of combined lesions of the oral cavity and gastrointestinal tract are not fully understood nowadays. There is no complete pathogenetic picture of changes both in oral cavity and in gastrointestinal tract. Scientific research data on above-mentioned diseases is fragmentary and not always linked. It is difficult to predict the course of combined diseases of the oral cavity and digestive tract.

In this regard, it is obvious that the treatment and prevention of lesions of the hard tissues of the teeth, the oral mucosa and inflammatory processes in the periodontium in children with chronic gastrointestinal pathology should be aimed at normalizing the general condition of the body, improving patients' quality of life.

\section{Directions for future research}

Further study of the dental status of children with diseases of the gastrointestinal tract is very valuable. The clarification of individual links of pathogenesis and the development of therapeutic and prophylactic measures and their introduction into dental practice is extremely important in dentistry and gastroenterology.

\section{Список літератури}

1. Поліщук ТВ. Прояви захворювань шлунковокишкового тракту в порожнині рота дітей. Вісник проблем біології і медицини. 2019; 1(150): 55-9.

2. Bui $F Q$, Almeida-da-Silva CLC, Huynh B, Trinh A, Liu J, Woodward J, Asadi H, Ojcius DM. Association between periodontal pathogens and systemic disease. Biomed J. 2019 Feb;42(1):27-35.

3. Шешукова ОВ, Падалка Al, Труфанова ВП, Поліщук ТВ, Мосієнко АС. Особливості поширення стоматологічної захворюваності у дітей із патологією органів шлунково-кишкового тракту. Український журнал медицини, біології та спорту. 2016; 1(1): 107-9.

4. Бауман СС, Шешукова ОВ. Вплив запальних захворювань шлунково-кишкового тракту на стан пародонту у дітей. Актуальні проблеми сучасної медицини: Вісник Української медичної стоматологічної академії. 2019; 4 (68): 118-22.

5. Хоменко ЛА. Стоматологический и иммунный статус детей с хроническими соматическими заболеваниями. Стоматология детского возраста и профилактика. 2013; 4 (47): 57-60.

6. Crippa R, Zuccotti GV, Mantegazza C. Oral manifestations of gastrointestinal diseases in children. Part 2: Crohn's disease. Eur J Paediatr Dent. 2016 Jun;17(2):164-6.
7. Hasan S, Ahmed S, Panigrahi R, Chaudhary $P$, Vyas V, Saeed S. Oral cavity and eating disorders: An insight to holistic health. J Family Med Prim Care. 2020 Aug 25;9(8):3890-7.

8. Крупей ВЯ. Сучасні уявлення про патогенез уражень твердих тканин зубів і пародонта та засоби їх лікування у дітей з хронічною патологією шлунково-кишкового тракту. Медичні перспективи. 2014; 19 (3):86-91.

9. Mantegazza C, Paglia M, Angiero F, Crippa R. Oral manifestations of gastrointestinal diseases in children. Part 4: Coeliac disease. Eur J Paediatr Dent. 2016 Dec;17(4):332-4.

10. Kitamoto S, Nagao-Kitamoto $H$, Hein R, Schmidt TM, Kamada N. The Bacterial Connection between the Oral Cavity and the Gut Diseases. J Dent Res. 2020 Aug;99(9):1021-9.

11. Mantegazza C, Angiero F, Zuccotti GV. Oral manifestations of gastrointestinal diseases in children. Part 3: Ulcerative colitis and gastrooesophageal reflux disease. Eur J Paediatr Dent. 2016 Sep;17(3):248-50.

12. Lauritano D, Boccalari E, Di Stasio D, Della Vella F, Carinci F, Lucchese A et al. Prevalence of Oral Lesions and Correlation with Intestinal Symptoms of Inflammatory Bowel Disease: A Systematic Review. Diagnostics (Basel). 2019 Jul 15;9(3):77.

13. Есаян 3В. Клиническая характеристика состояния тканей пародонта у больных с хроническим неспецифическим язвенным колитом. Український стоматологічний альманах. 2012;1:32-5.

14. Zhang Y, Qiao D, Chen R, Zhu F, Gong J, Yan F. The Association between Periodontitis and Inflammatory Bowel Disease: A Systematic Review and Meta-analysis. Biomed Res Int. 2021 Mar 12; 2021(1):1-8.

15. Xun Z, Zhang Q, Xu T, Chen N, Chen F. Dysbiosis and Ecotypes of the Salivary Microbiome Associated With Inflammatory Bowel Diseases and the Assistance in Diagnosis of Diseases Using Oral Bacterial Profiles. Front Microbiol. 2018 May 30;9:1136.

16. Каськова ЛФ, Акжитова ГО. Показник тесту емалевої резистентності у дітей із дисбактеріозом кишечника. Актуальні проблеми сучасної медицини: ВІСНИК Української медичної стоматологічної академії. 2010; 1 (29):131-3.

17. Лучинський МА, Рожко ВI, Басіста АС. Сучасні аспекти виникнення множинного карієсу та вплив захворювань шлунково-кишкового тракту на стан порожнини рота у дітей. Вісник проблем біології і медицини. 2018;1 (2):171-3.

18. Лукина ГИ, Базикян ЭА. Некариозные поражения твердых тканей зубов у гастроэнтерологических пациентов. Медицинский алфавит. 2010;4:31-2.

19. Клітинська ОВ, Мочалов ЮО, Пупена НВ. Особливості стоматологічного статусу дітей із хронічною гастродуоденальною патологією (огляд літератури). Проблеми клінічної педіатрії. 2014;1(23):53-9.

20. Петросян ЛБ. Диагностика и лечение нарушений прикуса, сочетающихся с заболеваниями внутренних органов [диссертация]. СПб; 2000. 19 с.

21. Vinesh E, Masthan K, Kumar MS, Jeyapriya SM, Babu A, Thinakaran M. A Clinicopathologic Study of Oral Changes in Gastroesophageal Reflux Disease, Gastritis, and Ulcerative Colitis. J Contemp Dent Pract. 2016;17:943-7. 
22. Cai H, Li W, Shu $X$, Peng $K$, Zhang $Y$, Jiang $M$. Genetic variation of Helicobacter pylori in the oral cavity and stomach detected using thymine adenine cloning in children with chronic gastritis. Pediatr Infect Dis J. 2014 Jan;33(1):1-6.

23. Mišak Z, Hojsak I, Homan, M. Review: Helicobacter pylori in pediatrics. Helicobacter. 2019; 24(1):63-9.

24. Abadi AT, Mobarez AM, Teymournejad O, Karbalaei M. Concomitant Colonization of Helicobacter pylori in Dental Plaque and Gastric Biopsy. J Pathog. 2014;4:87-91.

25. Yee JK. Helicobacter pylori colonization of the oral cavity: A milestone discovery. World J Gastroenterol. 2016 Jan 14;22(2):641-8.

26. Sarath Kumar KS, Mungara J, Venumbaka NR, Vijayakumar P, Karunakaran D. Oral manifestations of gastroesophageal reflux disease in children: A preliminary observational study. J Indian Soc Pedod Prev Dent. 2018 Apr-Jun;36(2):125-9.

27. Крючко ТО, Несіна ІМ. Особливості позастравохідних проявів гастроезофрагеальної рефлюксної хвороби у дітей. Здоровье ребенка. 2013;4:16-9.

28. Greuter T, Bertoldo F, Rechner R, Straumann A, Biedermann L, Zeitz J. et al. Extraintestinal manifestations of pediatric inflammatory bowel disease: Prevalence, presentation and anti-TNF treatment. J. Pediatric. Gastroenterol. 2017;65:2006.

29. Jajam $M$, Bozzolo $P$, Niklander $S$. Oral manifestations of gastrointestinal disorders. J Clin Exp Dent. 2017 Oct 1;9(10):1242-48.

30. Cappello F, Rappa F, Canepa F, Carini F, Mazzola M, Tomasello G. et al. Probiotics Can Cure Oral Aphthous-Like Ulcers in Inflammatory Bowel Disease Patients: A Review of the Literature and a Working Hypothesis. Int J Mol Sci. 2019 Oct 11;20(20):5026.

31. Каськова ЛФ, Акжитова ГО, Амосова ЛІ, Левченко HB, Бережна OE. Електрофоретична активність клітин букального епітелію в дітей із дисбактеріозом кишечнику. Вісник проблем біології і медицини. 2013; 2 (103):318-20.

32. Каськова ЛФ, Акжитова ГО. Мінералізуюча здатність ротової рідини у дітей із дисбактеріозом кишечнику. Український стоматологічний альманах. 2008;6:47-9.

33. Xun Z, Zhang Q, Xu T, Chen N, Chen F. Dysbiosis and Ecotypes of the Salivary Microbiome Associated With Inflammatory Bowel Diseases and the Assistance in Diagnosis of Diseases Using Oral Bacterial Profiles. Front Microbiol. 2018 May 30:9:1136.

34. Elmaghrawy K, Hussey S, Moran GP. The Oral Microbiome in Pediatric IBD: A Source of Pathobionts or Biomarkers? Front Pediatr. 2021 Jan 21;8:620254.

35. Дуда ОВ. Стан імунітету у дітей із хронічним катаральним гінгівітом та хронічними захворюваннями шлунково-кишкового тракту. Вісник проблем біології і медицини. 2012; 2 (97): 232-6.

\section{References}

1. Polishchuk TV. Proyavy zakhvoryuvan' shlunkovokyshkovoho traktu $v$ porozhnyni rota ditey. Visnyk problem biolohiyi i medytsyny. 2019; 1(150): 55-9. (Ukrainian).

2. Bui FQ, Almeida-da-Silva CLC, Huynh B, Trinh A, Liu J, Woodward J, Asadi H, Ojcius DM. Association between periodontal pathogens and systemic disease. Biomed J. 2019 Feb;42(1):27-35.

3. Sheshukova OV, Padalka Al, Trufanova VP, Polishchuk TV, Mosiienko AS. Osoblyvosti poshyrennya stomatolohichnoyi zakhvoryuvanosti u ditey iz patolohiyeyu orhaniv shlunkovo-kyshkovoho traktu. Ukrayins'kyy zhurnal medytsyny, biolohiyi ta sportu. 2016; 1(1): 107-9. (Ukrainian).

4. Bauman SS, Sheshukova OV. Vplyv zapal'nykh zakhvoryuvan' shlunkovo-kyshkovoho traktu na stan parodontu u ditey. Aktual'ni problemy suchasnoyi medytsyny: Visnyk Ukrayins'koyi medychnoyi stomatolohichnoyi akademiyi. 2019; 4 (68): 118-22. (Ukrainian).

5. Khomenko LA. Stomatologicheskiy i immunnyy status detey $s$ khronicheskimi somaticheskimi zabolevaniyami. Stomatologiya detskogo vozrasta i profilaktika. 2013; 4 (47): 57-60. (Russian).

6. Crippa R, Zuccotti GV, Mantegazza C. Oral manifestations of gastrointestinal diseases in children. Part 2: Crohn's disease. Eur J Paediatr Dent. 2016 Jun;17(2):164-6.

7. Hasan $S$, Ahmed $S$, Panigrahi $R$, Chaudhary $P$, Vyas V, Saeed S. Oral cavity and eating disorders: An insight to holistic health. J Family Med Prim Care. 2020 Aug 25;9(8):3890-7.

8. Krupey VYA. Suchasni uyavlennya pro patohenez urazhen' tverdykh tkanyn zubiv i parodonta ta zasoby yikh likuvannya $\mathrm{u}$ ditey $\mathrm{z}$ khronichnoyu patolohiyeyu shlunkovo-kyshkovoho traktu. Medychni perspektyvy. 2014; 19(3):86-91. (Ukrainian).

9. Mantegazza C, Paglia M, Angiero F, Crippa R. Oral manifestations of gastrointestinal diseases in children. Part 4: Coeliac disease. Eur J Paediatr Dent. 2016 Dec;17(4):332-4.

10. Kitamoto $S$, Nagao-Kitamoto $H$, Hein $R$, Schmidt TM, Kamada N. The Bacterial Connection between the Oral Cavity and the Gut Diseases. J Dent Res. 2020 Aug;99(9):1021-9.

11. Mantegazza C, Angiero F, Zuccotti GV. Oral manifestations of gastrointestinal diseases in children. Part 3: Ulcerative colitis and gastrooesophageal reflux disease. Eur J Paediatr Dent. 2016 Sep;17(3):248-250.

12. Lauritano D, Boccalari E, Di Stasio D, Della Vella F, Carinci $F$, Lucchese $A$ et al. Prevalence of Oral Lesions and Correlation with Intestinal Symptoms of Inflammatory Bowel Disease: A Systematic Review. Diagnostics (Basel). 2019 Jul 15;9(3):77.

13. Yesayan ZV. Klinicheskaya kharakteristika sostoyaniya tkaney parodonta u bol'nykh s khronicheskim nespetsificheskim yazvennym kolitom. Ukrains'kiy stomatologíchniy al'manakh. 2012;1:32-5. (Russian).

14. Zhang Y, Qiao D, Chen R, Zhu F, Gong J, Yan F. The Association between Periodontitis and Inflammatory Bowel Disease: A Systematic Review and Meta-analysis. Biomed Res Int. 2021 Mar 12; 2021(1):1-8.

15. Xun Z, Zhang Q, Xu T, Chen N, Chen F. Dysbiosis and Ecotypes of the Salivary Microbiome Associated With Inflammatory Bowel Diseases and the Assistance in Diagnosis of Diseases Using Oral Bacterial Profiles. Front Microbiol. 2018 May 30;9:1136.

16. Kas'kova LF, Akzhytova HO. Pokaznyk testu emalevoyi rezystentnosti u ditey iz dysbakteriozom 
kyshechnyka. Aktual'ni problemy suchasnoyi medytsyny: VISNYK Ukrayins'koyi medychnoyi stomatolohichnoyi akademiyi. 2010; 1 (29):131-3. (Ukrainian).

17. Luchyns'kyy MA, Rozhko VI, Basista AS. Suchasni aspekty vynyknennya mnozhynnoho kariyesu ta vplyv zakhvoryuvan' shlunkovo-kyshkovoho traktu na stan porozhnyny rota u ditey. Visnyk problem biolohiyi i medytsyny. 2018;1 (2):171-3. (Ukrainian).

18. Lukyna HY, Bazykyan ÉA. Nekaryoznye porazhenyya tverdykh tkaney zubov u hastroénterolohycheskykh patsyentov. Medytsynskyy alfavyt. 2010;4:31-2. (Russian).

19. Klityns'ka OV, Mochalov YUO, Pupena NV. Osoblyvosti stomatolohichnoho statusu ditey iz khronichnoyu hastroduodenal'noyu patolohiyeyu (ohlyad literatury). Problemy klinichnoyi pediatriyi. 2014;1(23):53-9. (Ukrainian)

20. Petrosyan LB. Dyahnostyka y lechenye narushenyy prykusa, sochetayushchykhsya s zabolevanyyamy vnutrennykh orhanov [dyssertatsyya]. SPb; 2000. 19 s. (Russian).

21. Vinesh E, Masthan K, Kumar MS, Jeyapriya SM, Babu A, Thinakaran M. A Clinicopathologic Study of Oral Changes in Gastroesophageal Reflux Disease, Gastritis, and Ulcerative Colitis. J Contemp Dent Pract. 2016;17:943-7.

22. Cai H, Li W, Shu $X$, Peng $K$, Zhang $Y$, Jiang $M$. Genetic variation of Helicobacter pylori in the oral cavity and stomach detected using thymine adenine cloning in children with chronic gastritis. Pediatr Infect Dis J. 2014 Jan;33(1):1-6.

23. Mišak Z, Hojsak I, Homan M. Review: Helicobacter pylori in pediatrics. Helicobacter. 2019; 24(1):63-9.

24. Abadi AT, Mobarez AM, Teymournejad O, Karbalaei M. Concomitant Colonization of Helicobacter pylori in Dental Plaque and Gastric Biopsy. J Pathog. 2014;4:87-91.

25. Yee JK. Helicobacter pylori colonization of the oral cavity: A milestone discovery. World J Gastroenterol. 2016 Jan 14;22(2):641-8.

26. Sarath Kumar KS, Mungara J, Venumbaka NR, Vijayakumar P, Karunakaran D. Oral manifestations of gastroesophageal reflux disease in children: A preliminary observational study. J Indian Soc Pedod Prev Dent. 2018 Apr-Jun;36(2):125-9.
27. Kryuchko TO, Nesina IM. Osoblyvosti pozastravokhidnykh proyaviv hastroezofaheal'noyi reflyuksnoyi khvoroby u ditey. Zdorov'e rebenka. 2013;4:16-9. (Russian).

28. Greuter $T$, Bertoldo $F$, Rechner R, Straumann A, Biedermann L, Zeitz J. et al. Extraintestinal manifestations of pediatric inflammatory bowel disease: Prevalence, presentation and anti-TNF treatment. J. Pediatric. Gastroenterol. 2017;65: 200-6.

29. Jajam $M$, Bozzolo $P$, Niklander $S$. Oral manifestations of gastrointestinal disorders. J Clin Exp Dent. 2017 Oct 1;9(10):1242-48.

30. Cappello F, Rappa F, Canepa F, Carini F, Mazzola M, Tomasello G. et al. Probiotics Can Cure Oral Aphthous-Like Ulcers in Inflammatory Bowel Disease Patients: A Review of the Literature and a Working Hypothesis. Int J Mol Sci. 2019 Oct 11;20(20):5026.

31. Kas'kova LF, Akzhytova HO, Amosova LI, Levchenko NV, Berezhna OE. Elektroforetychna aktyvnist' klityn bukal'noho epiteliyu $v$ ditey iz dysbakteriozom kyshechnyku. Visnyk problem biolohiyi i medytsyny. 2013; 2 (103):318-20. (Ukrainian).

32. Kas'kova LF, Akzhytova HO. Mineralizuyucha zdatnist' rotovoyi ridyny u ditey iz dysbakteriozom kyshechnyku. Ukrayins'kyy stomatolohichnyy al'manakh. 2008;6:47-9. (Ukrainian).

33. Xun Z, Zhang Q, Xu T, Chen N, Chen F. Dysbiosis and Ecotypes of the Salivary Microbiome Associated With Inflammatory Bowel Diseases and the Assistance in Diagnosis of Diseases Using Oral Bacterial Profiles. Front Microbiol. 2018 May 30;9:1136.

34. Elmaghrawy K, Hussey S, Moran GP. The Oral Microbiome in Pediatric IBD: A Source of Pathobionts or Biomarkers? Front Pediatr. 2021 Jan 21;8:620254.

35. Duda OV. Stan imunitetu u ditey iz khronichnym kataral'nym hinhivitom ta khronichnymy zakhvoryuvannyamy shlunkovo-kyshkovoho traktu. Visnyk problem biolohiyi i medytsyny. 2012; 2 (97): 232-6. (Ukrainian).

Стаття надійшла: 27.04.2021 p.

\section{Резюме}

У наш час питання поєднаних уражень порожнини рота і внутрішніх органів займають чільне місце серед проблем стоматології, оскільки дозволяють відобразити сутність генезу багатьох захворювань, що виявляються в порожнині рота.

Мета. Проаналізувати відомості щодо взаємозв'язку хвороб порожнини рота із захворюваннями різних відділів шлунково-кишкового тракту.

На думку багатьох вчених, при захворюваннях шлунково-кишкового тракту можуть спостерігатися зміни в порожнині рота: катаральний гінгівіт, стоматит, глосити, оскільки в цих випадках виникає дефіцит вітамінів групи В. А такі хвороби порожнини рота як хронічний рецидивуючий афтозний стоматит, плескатий лишай, хронічний рецидивуючий герпетичний стоматит, хронічний пародонтит, мають тяжчий перебіг за наявності патології травного тракту.

Висновки. Отже, анатомо-фрізіологічні особливості дітей, які хворіють на хронічні хвороби шкТ, диктують необхідність вивчення клінічних проявів стоматологічних хвороб у них.

Перспективи подальших досліджень. Подальше вивчення стоматологічного здоров'я дітей із захворюваннями шлунково-кишкового тракту на тлі уточнення окремих ланок патогенезу.

Ключові слова: травна система, стоматологічна захворюваність, гінгівіт, пародонтит, діти. 
UDC 616.31:616.33/.34-002]-053.3/.5

\section{SIGNS OF DISEASES OF THE GASTROINTESTINAL TRACT IN THE ORAL CAVITY OF CHILDREN}

\section{Maksymenko A.I.}

Poltava State Medical University, Poltava, Ukraine

\section{Summary}

The question of combined lesions of the oral cavity and internal organs occupy a prominent place among the problems of dentistry nowadays. They allow to reflect the genesis of many diseases that manifest themselves in the oral cavity.

Aim of the study was to analyze information on the relationship of diseases of oral cavity and various diseases of gastrointestinal tract.

Anatomical and physiological proximity, common innervation and humoral regulation leads to the involvement of organs of oral cavity in the pathological process. Catarrhal gingivitis, stomatitis are often caused by deficiency of vitamins of group B. Above-mentioned deficiency is caused, according to many scientists, by the diseases of gastrointestinal tract. And such diseases of the oral cavity as chronic recurrent stomatitis, lichen planus, chronic recurrent herpetic stomatitis, chronic periodontitis depends on the pathology of the digestive tract.

Conclusions. Thus, anatomical and physiological characteristics of children, who suffers from chronic gastrointestinal diseases, make us study the clinical manifestations of dental diseases in these patients.

Prospects for further research. Further study of the dental status of children with diseases of the gastrointestinal tract is very valuable.

Key words: digestive system, dental diseases, gingivitis, periodontitis, children. 